\title{
MENINGKATKAN KEMAMPUAN REPRESENTASI MATEMATIS SISWA MELALUI PENDEKATAN OPEN- ENDED DALAM PEMBELAJARAN MATEMATIKA
}

\section{(IMPROVING STUDENT'S MATHEMATIC REPRESENTATION ABILITY THROUGH AN OPEN-ENDED APPROACH IN LEARNING MATHEMATICS)}

\author{
Gita Dwi Fitriyani, S.Pd. ${ }^{1}$ \\ ${ }^{1}$ SMP NEGERI 8 KOTA BOGOR, gitadwif@yahoo.com
}

\begin{abstract}
Abstrak
Kemampuan representasi matematis diperlukan dalam proses pemecahan masalah, akan tetapi kemampuan representasi matematis siswa SMA masih rendah. Sehingga diperlukan pendekatan pembelajaran yang dapat meningkatkan kemampuan representasi matematis siswa. Tujuan dalam penelitian ini adalah 1) Mengetahui peningkatan kemampuan representasi matematis siswa dalam pembelajaran matematika setelah menggunakan pendekatan open-ended dengan siswa yang mendapatkan pembelajaran dengan pendekatan konvensional dan 2) Mengetahui respon siswa terhadap penerapan pembelajaran matematika dengan pendekatan open-ended. Populasi dalam penelitian ini adalah seluruh siswa SMA Negeri 2 Padalarang kelas X. Berdasarkan saran dari guru matematika, dipergunakan dua kelas sebagai sampel satu kelas sebagai kelas kontrol dan satu kelas lainnya sebagai kelas eksperimen. Desain penelitian yang digunakan dalam penelitian ini adalah desain kelompok kontrol pretes-postes. Instrumen penelitian yang digunakan adalah instrumen tes dan instrumen non tes berupa angket, lembar observasi, serta jurnal harian siswa. Hasil penelitian menunjukkan bahwa 1) Peningkatan kemampuan representasi matematis siswa yang mendapatkan pembelajaran dengan pendekatan open-ended lebih baik daripada dengan siswa yang mendapatkan pembelajaran dengan pendekatan konvensional 2) Sebagian besar siswa menunjukkan sikap positif terhadap pembelajaran open-ended dan menunjukkan sikap setuju terhadap pembelajaran open-ended untuk meningkatkan kemampuan representasi matematis.
\end{abstract}

Kata kunci: Open-ended, Representasi Matematis

\begin{abstract}
The ability of mathematical representation is needed in the problem solving process, but the ability of high school students to represent mathematical representation is still low. So that we need a learning approach that can improve students' mathematical representation skills. The objectives in this study were 1) Knowing the increase in students 'mathematical representation abilities in mathematics learning after using the open-ended approach with students who received conventional learning approaches and 2) Knowing the students' responses to the application of mathematics learning with an open-ended approach The population in this study were all students of SMA Negeri 2 Padalarang class X. Based on the advice of the mathematics teacher, two classes were used as samples, one class as the control class and the other as the experimental class. The research design used in this study
\end{abstract}


was a pretest-posttest control group design. The research instruments used were test instruments and non-test instruments in the form of questionnaires, observation sheets, and students' daily journals. The results show that 1) The increase in the mathematical representation ability of students who get learning with an open-ended approach is better than students who get learning with a conventional approach 2) Most of the students show a positive attitude towards open-ended learning and show an agreed attitude towards open-ended learning -ended to improve mathematical representation skills.

Keyword: Open-ended, Representation Mathematics

\section{PENDAHULUAN}

Dalam kehidupan sehari-hari sebagai manusia pasti dihadapkan pada suatu masalah yang harus diselesaikan. Untuk menyelesaikan permasalahan tersebut dibutuhkan kemampuan untuk mencerna informasi yang diperoleh secara cermat dan logis. Pada proses pemecahan masalah individu perlu melakukan proses kognitif seperti memahami kalimat masalah, memilih data yang diperlukan untuk solusi, menjawab masalah secara logis, dan menemukan berbagai alternatif pemecahan masalah. Selain itu, diperlukan kemampuan untuk merepresentasikan permasalahan tersebut ke dalam bentuk yang lebih mudah untuk dimengerti. Sebuah masalah akan lebih sederhana jika permasalahan tersebut dapat direpresentasikan dengan baik, sebaliknya jika representasi yang kurang tepat dapat membuat masalah tersebut menjadi sukar.

Dalam pembelajaran matematika, Brenner dkk. (Alhadad, 2010: 8) menyatakan bahwa proses dari kesuksesan pemecahan masalah bergantung pada keterampilan representasi yang meliputi konstruksi dan menggunakan representasi matematis dalam kata-kata, grafik, tabel dan persamaan, memecahkan manipulasi simbol. Menurut Suherman dkk. (2003: 83) melalui kegiatan pemecahan masalah aspek-aspek kemampuan matematika yang penting seperti penerapan aturan pada masalah tidak rutin, penemuan pola, penggeneralisasian, komunikasi matematis dan lain-lain dapat dikembangkan secara lebih baik. Representasi merupakan bagian dari kurikulum matematika. Salah satu keterampilan matematika yang perlu dikuasai siswa adalah kemampuan representasi matematis. Dalam National Council of Teachers of Mathematics (NCTM) beberapa kompetensi-kompetensi utama yang termasuk ke dalam kemampuan berpikir matematis yaitu kemampuan penalaran dan pembuktian, pemecahan masalah, komunikasi, koneksi dan representasi matematika.

Dalam NCTM (Alhadad, 2010: 7) dinyatakan bahwa kemampuan representasi matematis siswa sangat terbatas, sehingga ketika siswa memecahkan masalah, cara penyelesaian yang digunakannya cenderung melihat keterkaitan unsur-unsur penting dalam masalah tersebut, yang didominasi representasi simbolik, tanpa memperhatikan representasi bentuk lain. Dari hasil penelitian Trends in International Mathematics and Science Study (TIMSS) tahun 2007 (Gonzales, 2009), Indonesia menduduki urutan yang rendah yang menunjukkan peringkat matematika yaitu urutan ke-36 dari 48 negara yang disurvei. Ada dua aspek yang dinilai oleh TIMSS yaitu aspek materi dan aspek kognitif. Untuk aspek kognitif yang dinilai yaitu pemahaman (knowing), penerapan (applying) dan penalaran (reasoning), dimana kemampuan representasi termasuk dalam 
penerapan (applying) dan pemahaman (knowing). Rata-rata skor yang diperoleh Indonesia untuk pemahaman (knowing) adalah 397, penerapan (applying) adalah 398, dan penalaran (reasoning) adalah 405 dari skala rata-rata 500. Dari data tersebut menunjukkan bahwa kemampuan representasi matematis siswa masih rendah di Indonesia. Dari hasil studi Hudiono (2005) mengatakan bahwa menurut guru representasi seperti tabel, gambar disampaikan kepada siswa, sebagai penyerta atau pelengkap dalam penyampaian materi jarang memperhatikan representasi yang dikembangkan siswa. Sejalan dengan pendapat Sumarmo (dalam Darliman, 2009: 2) kemampuan siswa SMA kelas X dalam menyelesaikan matematika belum memuaskan. Hal ini terjadi karena terdapat perbedaan antara yang dipahami dengan apa yang disampaikan. Aspek yang menyebabkan hal tersebut adalah kemampuan representasi siswa yang masih rendah.

Kemampuan represenrasi matematis perlu ditingkatkan karena masih rendahnya kemampuan representasi matematis siswa SMA, selain itu representasi merupakan salah satu standar proses. McCoy, Baker dan Little (Jaenudin, 2008: 3) mengemukakan bahwa cara terbaik membantu siswa memahami matematika melalui representasi adalah dengan mendorong mereka untuk menemukan atau membuat representasi sebagai alat berpikir dalam mengkomunikasikan gagasan matematika. Ruseffendi (Jaenudin, 2008: 3) mengemukakan bahwa salah satu peran penting dalam mempelajari matematika adalah memahami objek langsung matematika yang bersifat abstrak seperti: fakta, konsep, prinsip dan skill. Untuk memahami matematika yang abstrak diperlukan kemampuan representasi matematis.

Dari penjelasan di atas, kemampuan representasi matematis merupakan hal yang penting dalam pembelajaran matematika, sehingga diperlukan suatu pembelajaran yang dapat mengasah kemampuan tersebut. Pendekatan pembelajaran yang diarahkan untuk menciptakan representasi pada proses pemecahan masalah penting bagi siswa. Salah satu pendekatan dalam pembelajaran matematika yaitu pendekatan pemecahan masalah. NCTM (Alhadad, 2010: 54) menekankan pemakaian strategi yang beragam untuk memecahkan masalah, dan merekomendasikan guru untuk mendorong siswa menerapkan strategi ini termasuk memanipulasi, mencoba-coba (trial and error), mencoba kasus perkasus atau nilai khusus, menebak mengecek, mendaftar berbagai kemungkinan, mengumpulkan dan mengorganisasi data dalam tabel, mencari suatu pola dari tabel, menggambar suatu diagram, dan bekerja mundur.

Pendekatan pemecahan masalah merupakan fokus dalam pembelajaran matematika, dimana mencakup masalah tertutup dan masalah terbuka. Masalah terbuka atau open-ended problem memiliki solusi tidak tunggal dan berbagai cara penyelesaian. Dalam memecahkan masalah perlu dikembangkan keterampilan memahami masalah, membuat model matematika, menyelesaikan masalah, dan menafsirkan solusinya. Selain itu, menurut Takahashi (2008) dengan open-ended problem pembelajaran matematika dapat dirancang sedemikian sehingga lebih memberikan kesempatan kepada siswa untuk mengembangkan kompetensi mereka dalam menggunakan ekspresi matematik dan persamaan. Pembelajaran open-ended juga mengharuskan siswa untuk menjelaskan pemikirannya ke dalam representasi yang beragam seperti gambar, simbol, ekspresi matematis, kata-kata, dan grafik. Oleh karena itu, salah satu alternatif pendekatan pembelajaran yang dapat meningkatkan kemampuan representasi matematis adalah open-ended. 
Siswa pada kehidupannya sehari-hari akan dihadapkan pada masalah. Karena itu pembelajaran pemecahan masalah diperlukan agar siswa terbiasa dalam menyelesaikan permasalahannya di kehidupan sehari-hari. Pendekatan open-ended dalam pembelajaran matematika juga dapat menantang pikiran siswa sehingga dapat meningkatkan rasa keingintahuan dan motivasi untuk belajar matematika. Selain itu dapat memberikan siswa banyak pengalaman dalam menafsirkan masalah dan menghasilkan ide-ide yang berbeda dalam menyelesaikan masalah. Hal tersebut memungkinkan siswa untuk menggunakan representasi untuk mencari solusi dari masalah tersebut dengan berbagai kemungkinan. Diharapakan pendekatan open-ended dapat meningkatkan kemampuan representasi matematis.

Berdasarkan latar belakang tersebut, penulis tertarik untuk meneliti pembelajaran matematika dengan pendekatan open-ended untuk mengingkatkan kemampuan representasi matematis siswa SMA. Adapun tujuan penelitian ini adalah sebagai berikut.

1) Mengetahui peningkatan kemampuan representasi matematis siswa dalam pembelajaran matematika setelah menggunakan pendekatan open-ended dengan siswa yang mendapatkan pembelajaran dengan pendekatan konvensional.

2) Mengetahui respon siswa terhadap penerapan pembelajaran matematika dengan pendekatan open-ended.

\section{KAJIAN TEORI}

\section{A. Kemampuan Representasi Matematis}

Representasi matematis merupakan komponen utama dalam kemampuan berpikir matematis. Seperti disebutkan dalam National Council of Teacher of Mathematics (NCTM) beberapa kompetensi-kompetensi utama yang termasuk ke dalam kemampuan berpikir matematis yaitu kemampuan penalaran dan pembuktian, pemecahan masalah, komunikasi, koneksi dan representasi matematika. Menurut Jones dan Knuth (Alhadad, 2010: 33) representasi adalah model atau bentuk pengganti dari situasi masalah atau aspek dari suatu situasi masalah yang digunakan untuk menemukan solusi. Dalam NCTM simbol, bersama dengan alat peraga seperti bagan dan grafik harus dipahami oleh siswa sebagai cara mengkomunikasikan ide-ide dalam matematika kepada orang lain. Jenis representasi yang sering digunakan yaitu simbol, tabel, gambar, grafik, ekspresi matematis, dan kata-kata.

Dalam NCTM standar proses representasi program pengajaran dari pra taman kanak-kanak sampai kelas 12 harus memungkinkan siswa untuk:

1) Menciptakan dan menggunakan representasi untuk mengorganisir, mencatat, dan mengkomunikasikan ide-ide matematika.

2) Memilih, menerapkan, dan menerjemahkan representasi matematis untuk memecahkan masalah.

3) Menggunakan representasi untuk memodelkan dan menginterpretasikan secara fisik, sosial dan fenomena matematika.

Representasi dalam pembelajaran matematika akan membantu siswa untuk memahami konsep. Menurut Janvier (Amri, 2009: 16), memahami konsep atau ide-ide matematika oleh siswa adalah sebagai berikut. 
1) Siswa dapat mengenali ide-ide yang diselipkan dalam beragam sistem representasi yang berbdea secara kualitatif

2) Siswa dapat secara fleksibel memanipulasi ide-ide di dalam sistem representasi tertentu

3) Siswa dapat secara akurat menerjemahkan ide-ide dari satu sistem ke sistem lain

Hiebert dan Carpenter (Yulianti, 2011: 17) mengemukakan bahwa pada dasarnya representasi dapat dinyatakan sebagai representasi internal dan representasi eksternal. Representasi internal merupakan aktivitas mental di dalam otak, sedangkan reprsentasi eksternal merupakan ungkapan dari representasi internal. Menurut Jones (2000) seseorang tidak dapat mengobservasi proses representasi internal siswa, tetapi dapat menduga bentuk mental siswa dari apa yang siswa katakan atau lakukan. Representasi internal dan eksternal saling berkaitan erat, ketika representasi internal siswa tidak berjalan dengan baik maka siswa tersebut tidak memiliki gagasan untuk direpresentasikan. Begitu sebaliknya, ketika kemampuan representasi eksternalnya kurang, apa yang telah dipikirkan tidak dapat tersampaikan dengan baik.

Lesh (Nakahara, 2008) menyatakan representasi menjadi lima macam yang digunakan dalam matematika yaitu representasi gambar, representasi bahasa lisan, representasi model manipulatif, representasi situasi nyata, dan representasi simbol tertulis. Adapun dalam penelitian ini, indikator kemampuan representasi yang diamati pada siswa adalah sebagai berikut.

1) Representasi visual berupa diagram, grafik atau tabel meliputi:

a) Menggunakan representasi visual untuk menyelesaikan masalah.

b) Membuat gambar untuk memperjelas masalah dan menyelesaikannya.

2) Ekspresi matematis, meliputi:

a) Menyelesaikan masalah dengan melibatkan ekspresi matematis.

b) Membuat persamaan atau model matematis dari representasi lain yang diberikan

3) Kata-kata atau teks tertulis, meliputi:

a) Menjawab soal dengan menggunakan kata-kata atau teks tertulis.

b) Menuliskan langkah-langkah penyelesaian matematik dengan kata-kata.

\section{B. Pendekatan Open-Ended}

Pembelajaran dengan pendekatan open-ended diawali dengan memberikan sebuah permasalahan yang terbuka kepada siswa. Dalam menyelesaikan permasalahan tersebut siswa memiliki banyak kemungkinan solusi. Menurut Nohda (dalam Suherman dkk., 2003: 15) tujuan pembelajaran open-ended adalah untuk membantu mengembangkan kegiatan kreatif dan pola pikir matematis siswa melalui problem solving secara simultan. Pengertian dari open-ended problem menurut Takahashi (2008) adalah soal yang mempunyai banyak solusi atau strategi penyelesaian. Sedangkan menurut Shimada (dalam Mahmudi, 2008) pembelajaran open-ended adalah pembelajaran yang menyajikan suatu permasalahan yang memiliki metode atau penyelesaian yang benar lebih dari satu. Pada dasarnya open-ended lebih menekankan pada proses untuk mendapatkan suatu jawaban dalam suatu permasalahan.

Pembelajaran open-ended mengharuskan siswa untuk menjelaskan pemikirannya agar guru dapat memahami tanggapan dan pemikiran setiap siswa 
terhadap masalah yang diberikan. Manfaat dari penggunaan soal terbuka (openended problem) dalam pembelajaran matematika menurut Takahashi (2008) yaitu sebagai berikut.

1) Siswa berpartisipasi secara lebih aktif dalam pembelajaran dan mengekspresikan ide-ide mereka secara lebih intensif.

2) Siswa mempunyai kesempatan lebih untuk menggunakan pengetahuan dan keterampilanya secara komprehensif.

3) Siswa mempunyai kesempatan lebih untuk mengembangkan penalarannya.

4) Siswa mempunyai pengalaman yang kaya untuk menikmati proses penemuan dan menerima persetujuan dari siswa lainnya terhadap strategi atau solusi yang mereka hasilkan.

Suherman dkk. (2003) mengemukakan bahwa dalam kegiatan matematika dan kegiatan siswa disebut terbuka jika memenuhi ketiga aspek berikut:

1) Kegiatan siswa harus terbuka

2) Kegiatan matematik adalah ragam berpikir

3) Kegiatan siswa dan kegiatan matematik merupakan satu kesatuan.

Menurut Shimada (Kusumah, 2010) pendekatan open ended merupakan suatu pendekatan dalam pembelajaran yang diawali dengan pengenalan pada sebuah masalah terbuka. Setelah pengenalan masalah, pembelajaran dilanjutkan dengan memberikan sebuah jawaban yang benar dari masalah yang dimunculkan, sebagai contoh kepada siswa tentang cara-cara menemukan jawaban dalam proses pembelajaran. Melalui kegiatan ini diharapkan siswa dapat menjawab permasalahan dengan banyak cara yang beragam, yang dapat memunculkan representasi dari sebuah masalah yang beragam. Selain itu Moon dan Schulman (Kusumah, 2010) mengatakan bahwa penggunaan masalah terbuka pada pendekatan open ended seringkali menuntut penjelasan siswa tentang pemikiran mereka, sehingga guru dapat memperoleh pengertian yang mendalam dari gayagaya belajar mereka, bahasa yang mereka gunakan untuk menguraikan ide-ide matematis dan interpretasi mereka tentang suatu situasi matematis. Dari penjelasan siswa mengenai jawaban permasalahan, guru dapat mengetahui kemampuan setiap siswa dalam merepresentasikan setiap masalah dan cara penyelesaiannya.

Pembelajaran matematika dengan pendekatan open-ended di awali dengan memberikan masalah terbuka pada siswa, untuk menyusun pertanyaan openended menurut Cooney (dalam Kusumah, 2010) terdapat beberapa langkah yang dijadikan sebagai acuan yaitu sebagai berikut.

1) Meminta siswa untuk membuat sebuah situasi atau contoh yang memenuhi syarat tertentu

2) Meminta siswa untuk menjelaskan siapa yang benar dan mengapa

3) Meminta siswa untuk menyelesaikan suatu masalah dan menjelaskan

Selain itu menurut Suherman dkk (2003) untuk mengembangkan openended problem ada beberapa hal yang dapat menjadi acuan, yaitu:

1) Sajikan permasalahan melalui situasi fisik yang nyata di mana konsep-konsep matematika dapat diamati dan dikaji siswa.

2) Soal-soal pembuktian dapat diubah sedemikian rupa sehingga siswa dapat menemukan hubungan dan sifat-sifat dari variabel dalam persoalan itu. 
3) Sajikan bentuk-bentuk atau bangun-bangun (geometri) sehingga siswa dapat membuat suatu konjektur.

4) Sajikan urutan bilangan atau tabel sehingga siswa dapat menemukan aturan matematika.

5) Berikan beberapa contoh konkrit dalam beberapa kategori sehingga siswa bisa mengelaborasi sifat-sifat dari contoh itu untuk menemukan sifat-sifat yang umum.

6) Berikan beberapa latihan serupa sehingga siswa dapat menggeneralisasi dari pekerjaaanya.

Kusumah (2010) mengatakan garis besar langkah pembelajarannya meliputi kegiatan awal, kegiatan inti, dan kegiatan akhir. Kegiatan ini mencakup kegiatan memberikan masalah, merekam respon yang diharapkan dari siswa, membahas respon siswa, dan meringkas apa yang telah dipelajari.

\section{METODE}

Tujuan yang akan dicapai dalam penelitian ini yaitu mengetahui perbandingan peningkatan kemampuan representasi matematis antara siswa yang mendapatkan pembelajaran dengan pendekatan open-ended dan siswa yang menggunakan metode ekspositori. Berdasarkan tujuan penelitian, maka penelitian ini adalah penelitian kuasi eksperimen. Perlakuan yang dilakukan terhadap variabel bebas dapat dilihat hasilnya pada variabel terikat. Variabel bebas dalam penelitian ini yaitu pembelajaran melalui pendekatan open-ended dan variabel terikatnya kemampuan representasi matematis siswa. Populasi dalam penelitian ini adalah seluruh siswa kelas SMA Negeri 2 Padalarang kelas $X$ tahun ajaran 2011/2012 sedangkan sampelnya akan dipilih dua kelas sebagian dari populasi. Berdasarkan saran dari guru matematika, dipergunakan dua kelas sebagai sampel yaitu kelas X-4 sebagai kelas kontrol dan kelas X-8 sebagai kelas eksperimen. Desain penelitian yang digunakan dalam penelitian ini adalah desain kelompok kontrol pretes-postes. Instrumen tes yang digunakan adalah pretes dan postes. Tes ini diberikan dengan tujuan untuk mengetahui kemampuan representasi matematis. Sedangkan instrumen nontes yang digunakan adalah angket, lembar observasi, dan jurnal harian siswa.

\section{HASIL DAN PEMBAHASAN}

Pembahasan dilakukan berdasarkan data hasil penelitian dan teori yang telah dianalisis yaitu mengenai kemampuan representasi matematis siswa, sikap siswa terhadap pembelajaran dengan pendekatan open-ended, dan pelaksanaan pembelajaran dengan pendekatan open-ended. Mengenai kemampuan representasi matematis siswa, berdasarkan data pretes yang diperoleh rata-rata kemampuan awal dari kelas kontrol dan kelas eksperimen tidak memiliki perbedaan yang cukup besar yaitu 0,99. Rata-rata kemampuan awal kelas kontrol lebih rendah dibandingkan dengan rata-rata kelas eksperimen. Pada uji statistik rata-rata skor pretes dengan taraf signifikansi 0,05, diperoleh bahwa rata-rata kemampuam awal representasi matemais kedua kelas adalah sama.

Setelah diberikan pembelajaran dengan menggunakan metode ekspositori untuk kelas kontrol dan pendekatan open-ended untuk kelas eksperimen siswa diberikan postes. Dari hasil postes yang diperoleh, kedua kelas tersebut memiliki pencapaian yang berbeda pada hasil rata-rata kemampuan representasi matematis. 
Rata-rata hasil postes kelas kontrol adalah 35,18 dan kelas eksperimen adalah 44,2. Terdapat perbedaan antara hasil postes kelas kontrol dengan kelas eksperimen yaitu 9,08, dimana rata-rata hasil postes kelas ekperimen lebih besar dibandingkan dengan kelas kontrol. Setelah dilakukan uji statistik dengan taraf signifikansi 0,05 diperoleh bahwa pencapaian kemampuan representasi matematis siswa kelas eksperimen lebih baik dibandingkan kelas kontrol. Begitu pula dengan peningkatan kemampuan representasi matematis kelas eksperimen lebih baik dibandingkan kelas kontrol. Hal ini dapat dilihat dari rata-rata indeks gain kelas eksperimen lebih besar dibandingkan kelas kontrol. Untuk rata-rata indeks gain kelas kontrol adalah 0,20 dan kelas eksperimen adalah 0,31.

Kualitas peningkatan kemampuan representasi matematis dilihat dari ratarata indeks gain, rata-rata indeks gain untuk kelas kontrol termasuk kategori rendah dan rata-rata indeks gain untuk kelas eksperimen termasuk kategori sedang. Kualitas peningkatan yang berbeda antara kelas kontrol dan kelas eksperimen, karena kedua kelas diberikan pembelajaran yang berbeda. Pada kelas eksperimen, siswa mendapatkan pembelajaran dengan pendekatan open-ended. Menurut Suherman (2003) pada pembelajaran tersebut kegiatan harus terbuka, siswa diberikan kesempatan untuk melakukan segala sesuatu sesuai keinginannya. Begitu juga dalam menyelesaikan permasalahan siswa dapat memilih berbagai representasi untuk menyampaikan ide-ide mereka. Dengan demikian dapat disimpulkan bahwa kemampuan representasi matematis siswa yang mendapatkan pembelajaran dengan pendekatan open-ended lebih baik daripada siswa yang mendapatkan pembelajaran dengan metode ekspositori. Hal ini sejalan dengan pendapat Takhahasi yaitu pembelajaran matematika dengan open-ended problem dirancang sedemikian sehingga lebih memberikan kesempatan siswa untuk kompetensi mereka dalam menggunakan ekspresi matematik dan persamaan.

Sikap siswa tehadap pembelajaran dengan pendekatan open-ended, dapat dilihat dari hasil analisis angket sikap siswa. Sebagian besar siswa menunjukkan sikap positif terhadap pembelajaran dengan pendekatan open-ended. Hal ini ditunjukkan dengan persentase dari rata-rata skor indikator 1 yang lebih dari 3 yaitu 68,57\%. Selain itu siswa juga menunjukkan sikap setuju terhadap pembelajaran dengan pendekatan open-ended dapat meningkatkan kemampuan representasi matematis, hal tersebut dapat dilihat persentase dari rata-rata skor indikator 2 yang lebih dari 3 yaitu 51,42\%. Berdasarkan hasil pembahasan tersebut dapat disimpulkan bahwa siswa menunjukkan sikap positif terhadap pembelajaran dengan pendekatan open-ended.

Untuk pelaksanaan pembelajaran dengan pendekatan open-ended dapat dilihat dari analisis data lembar observasi. Dari hasil analisis diperoleh hasil pada kegiatan awal keterlaksanaan dari kegiatan siswa dan guru adalah 87,5\%. Hal ini dikarenakan pada pertemuan awal siswa masih belum bisa beradaptasi dengan pembelajaran seperti ini serta peneliti lupa untuk memotivasi siswa. Pada kegiatan memberikan masalah persentase keterlaksanaannya adalah 100\%. Kegiatan memberikan masalah merupakan hal yang penting dalam pembelajaran openended. Pembelajaran dengan pendekatan open-ended diawali dengan memberikan masalah terbuka kepada siswa.

Pada kegiatan inti yaitu mengeksplorasi masalah keterlaksanaan kegiatan siswa adalah $91,7 \%$ dan kegiatan guru adalah $87,5 \%$, karena pada pertemuan ketiga alokasi waktu yang kurang sesuai sehingga guru tidak memberikan 
kesempatan kepada siswa untuk mengerjakan lembar kegiatan siswa secara individu tetapi langsung mengerjakan secara kelompok. Untuk kegiatan merekam respon persentase keterlaksanaannya juga tidak $100 \%$ melainkan untuk kegiatan siswa adalah 83,3\% sedangkan untuk kegiatan guru adalah 87,5\%. Hal ini dikarenakan pada saat pertemuan ketiga dengan materi menggambar bangun ruang siswa kesulitan menggambarkan hasil diskusi di depan kelas karena keterbatasan alat dan pada pertemuan keempat dan kelima dengan materi irisan bangun datar siswa mengalami kesulitan dalam menentukan kemungkinan kedudukan titik. Setelah menentukan banyaknya penyelesaian yang mungkin, guru dapat memberi bantuan kepada siswa yang mengalami kesulitan. Sedangkan untuk kegiatan meringkas ketercapaian pelaksanaan kegiatan siswa adalah 87,5\% dan kegiatan guru adalah 75\%. Keterlaksanaan yang tidak $100 \%$ ini dikarenakan pada pertemuan ketiga siswa kebingungan ketika diminta menyimpulkan langkahlangkah untuk menggambar bangun ruang serta pada pertemuan keepat dan kelima guru tidak memberikan soal latihan dikarenakan waktu yang tidak mencukupi. Untuk kegiatan akhir siswa tidak diobservasi karena kegiatan akhir lebih dititikberatkan pada guru. Untuk keterlaksanaan kegiatan akhir yang dilakukan oleh guru adalah $75 \%$, karena pada beberapa pertemuan tidak terjadi miskonsepsi, sehingga guru tidak perlu meluruskan konsep yang kurang tepat.

\section{SIMPULAN DAN SARAN}

\section{Kesimpulan}

Berdasarkan hasil penelitian dan pembahasan mengenai pembelajaran dengan pendekatan open-ended terhadap peningkatan kemampuan representasi matematis siswa SMA dapat diperoleh kesimpulan bahwa peningkatan kemampuan representasi matematis siswa yang mendapatkan pembelajaran dengan pendekatan open-ended lebih baik dibandingkan dengan siswa yang mendapatkan pembelajaran dengan pendekatan konvensional. Sebagian besar siswa menunjukkan sikap positif terhadap pembelajaran open-ended dan menunjukkan sikap setuju terhadap pembelajaran open-ended untuk meningkatkan kemampuan representasi matematis.

\section{Saran}

Berdasarkan hasil penelitian dan kesimpulan yang diperoleh, terdapat beberapa saran yang dapat dikemukakan yaitu sebagai berikut.

1) Sebaiknya pendekatan open-ended digunakan dalam pembelajaran matematika sebagai alternatif pembelajaran untuk meningkatkan kemampuan representasi matematis siswa.

2) Kualitas peningkatan pencapaian kemampuan representasi matematis siswa dengan pendekatan open-ended dalam penelitian ini termasuk kategori sedang. Disarankan untuk pembelajaran dengan pendekatan open-ended untuk mengoptimalkan pembelajaran yaitu dengan mempersiapkan masalah terbuka dan kemungkinan jawabannya serta pengaturan waktu yang tepat dalam pelaksanaan pembelajaran.

3) Penelitian terhadap pendekatan open-ended disarankan untuk diujicobakan pada jenjang pendidikan yang lainnya. 


\section{DAFTAR RUJUKAN}

Alhadad, S.F. (2010). Meningkatkan Kemampuan Representasi Multipel Matemasis, Pemecahan Masalah Matematis, dan Self Esteem Siswa SMP Melalui Pembelajaran dengan Pendekatan Open Ended. Disertasi tidak diterbitkan. Bandung: Sekolah Pascasarjana Universitas Pendidikan Indonesia.

Darliman, D. (2009). Perbandingan Kemampuan Representasi Matematis Siswa Sekolah Menengah Atas yang Pembelajarannya Menggunakan Pendekatan Double Loop Problem Solving dan Pembelajaran Konvensional. Skripsi tidak diterbitkan. Bandung: Universitas Pendidikan Indonesia.

Gonzales, P. dkk. (2009). Highlights From TIMSS 2007: Mathematics and Science Achievement of U.S Fourth-and Eight-Grade Students in an International Context. National Center for Education Statistics, Institute of Education Sciences, U.S. Department of Education. Washington, DC.

Hudiono, B. (2005). Peran Pembelajaran Diskursus Multi Representasi Terhadap Pengembangan Kemampuan Matematik dan Daya Representasi Pada Siswa SLTP. Disertasi tidak diterbitkan. Bandung: Sekolah Pascasarjana Universitas Pendidikan Indonesia.

Jaenudin. (2008). Pengaruh Pendekatan Kontekstual Terhadap Kemapuan Representasi Matematik Beragam Siswa Sekolah Menengah Pertama. Skripsi tidak diterbitkan. Bandung: Universitas Pendidikan Indonesia.

Jones, A.D. (2000). The Fifth Process Standard: An Argument to Include Representation in $\quad$ Standars 2000. [Online]. Tersedia: http://wwwusers.math.umd.edu/ dac/650old/jonespaper.html [7Oktober 2011]

Kusumah, Y.S. (2010). Pembelajaran Matematika Melalui Pendekatan Open-Ended. Bandung: FPMIPA UPI.

Nakahara, T. (2008). Cultivating Mathematical Thinking through Representation. [Online].Tersedia:http://www.ceiced.tsukuba.ac.jp/math/apec/apec2008/papers.PDF/ 1.Keynote(Dec.9) Tadao Nakahara Japan.pdf [11 Juni 2012]

Ruseffendi. (2005). Dasar-dasar Penelitian Pendidikan dan Bidang Non-Eksakta Lainnya. Bandung: Tarsito.

Suherman, E. dkk. (2003). Strategi Pembelajaran Matematika Kontemporer. Bandung: JICA UPI.

Takahashi, A. (2008). Communication as Process for Students to Learn Mathematical. [Online].Tersedia:http://www.criced.tsukuba.ac.jp/math/apec/apec2008/papers/PDF/ 14.Akihiko_Takahashi_USA.pdf [11 Juni 2012]

Yulianti, I. (2011). Penerapan Model Pembelajaran Knisley-Mulyana dalam Upaya Menigkatkan Kemampuan Representasi Matematis Siswa. Skripsi tidak diterbitkan. Bandung: Universitas Pendidikan Indonesia. 